\title{
Cell Biological Studies of the Prion Protein
}

\author{
David A. Harris \\ Department of Cell Biology and Physiology, Washington University School of \\ Medicine, St. Louis, Missouri, USA
}

\begin{abstract}
Studying $\mathrm{PrP}^{\mathrm{C}}$ and $\mathrm{PrP}^{\mathrm{Sc}}$ in cell culture systems is advantageous because such systems contain all the organelles, membranes, and molecular cofactors that are likely to play an important role in the biology of the proteins. Using cultured cells expressing $\mathrm{PrP}^{\mathrm{C}}$, we have discovered that this isoform constitutively cycles between the cell surface and an endocytic compartment, a process that is mediated by clathrin-coated pits and a putative $\operatorname{PrP}^{\mathrm{C}}$ receptor. We have also constructed stably transfected lines of $\mathrm{CHO}$ cells that express PrP molecules carrying mutations that are associated with familial prion diseases. The mutant PrP molecules in these cells are spontaneously converted to the PrPsc ${ }^{\mathrm{Sta}}$, a phenomenon which has allowed us to analyze several key features of prion formation.
\end{abstract}

\section{Introduction}

Prion diseases are fatal neurodegenerative disorders which have an infectious, genetic, or sporadic origin. All cases are attributable to a conformational change in a normal cellular protein, designated $\mathrm{PrP}^{\mathrm{C}}$, which converts it into a pathogenic isoform, referred to as $\operatorname{PrP}^{\mathrm{Sc}}(1,39)$. Exactly how this transformation occurs at the structural level is unclear at present, but it appears to involve generation of additional regions of $\beta$-sheet in the polypeptide chain at the expense of $\alpha$-helical or unstructured domains (39). In infectious prion diseases, which include kuru as well as new-variant and iatrogenic Creutzfeldt-Jakob disease (CJD) in humans, and experimental scrapie in animals, exogenous $\mathrm{PrP}^{\mathrm{Sc}}$ is thought to impress its conformation on endogenous host $\mathrm{PrP}^{\mathrm{C}}$, thereby generating more $\mathrm{PrP}^{\mathrm{Sc}}$ in an auto-catalytic reaction (2). In familial forms, which include Gerstmann-Sträussler syndrome (GSS), fatal familial insomnia (FFI), and about $10 \%$ of the cases of CJD, germline mutations in the PrP gene are presumed to induce conversion of the protein to the PrP state (39). Sporadic forms, which comprise most cases of CJD, may result from rare, spontaneous conversion of wild-type $\operatorname{PrP}$ to $\mathrm{PrP}^{\mathrm{Sc}}$, or from somatic mutations in the PrP gene (3).

My laboratory has been interested in studying prion diseases from a cell biological perspective. In particular, we are investigating how $\mathrm{PrP}^{\mathrm{C}}$ and $\mathrm{PrP}^{\mathrm{Sc}}$ are post-translationally processed and metabolized, how they are localized and targeted after synthesis, what other cellular molecules they interact with, and how they cause the clinical and neuropathological abnormalities characteristic of the disease state. Our primary objectives are to elucidate the cellular and molecular mechanisms underlying conversion of $\mathrm{PrP}^{\mathrm{C}}$ into $\mathrm{PrP}^{\mathrm{Sc}}$, as well as to understand the normal cellular function of $\mathrm{PrP}^{\mathrm{C}}$. A cell biological approach has an important advantage: It allows one to study PrP biology in the context of the organelles, membranes, and molecular cofactors that undoubtedly play an important role in the function of the two isoforms of the protein. For example, chaperone molecules are now widely thought to play 
an important role in prion formation, and identification of these proteins represents an important challenge in the field (4). Cultured cells that are susceptible to scrapie infection presumably contain all the chaperones required for prion propagation, in contrast to in vitro systems based on purified PrP and peptides which will lack these essential cofactors. By permeabilizing, breaking open, or fractionating cultured cells, it should be possible to develop systems where $\mathrm{PrP}^{\mathrm{Sc}}$ generation can be achieved at high efficiency under conditions where the activity of chaperones can be experimentally manipulated and assayed.

In this review, I will first discuss our work on the cellular trafficking of $\operatorname{PrP}^{\mathrm{C}}$, which bears on the normal physiological function of this isoform, and the possible cellular routes along which it is converted to $\mathrm{PrP}^{\mathrm{Sc}}$. I will then describe a transfected cell system which we have developed that generates $\mathrm{PrP}^{\mathrm{Sc}}$ de novo from $\mathrm{PrP}$ molecules carrying pathogenic mutations.

\section{Trafficking of $\operatorname{PrP}^{\mathrm{C}}$}

Experiments using transfected cell lines indicate that $\operatorname{PrP}^{\mathrm{C}}$ constitutively cycles between the plasma membrane and an early endocytic compartment (Figure 1). This conclusion is based on several lines of evidence (5). First, it is possible to directly measure internalization and recycling of surface $\operatorname{PrP}^{\mathrm{C}}$ molecules that have been labeled with membrane-impermeant iodination or biotinylation reagents. Kinetic analysis of these data indicate that $\mathrm{PrP}^{\mathrm{C}}$ molecules cycle through cultured neuroblastoma cells with a transit time of $\sim 60$ minutes. Second, endocytosis of $\mathrm{PrP}^{\mathrm{C}}$ can be visualized by using immunofluorescence microscopy to track internalization of antibodies that have been bound to $\operatorname{PrP}^{\mathrm{C}}$ on the cell surface. Third,

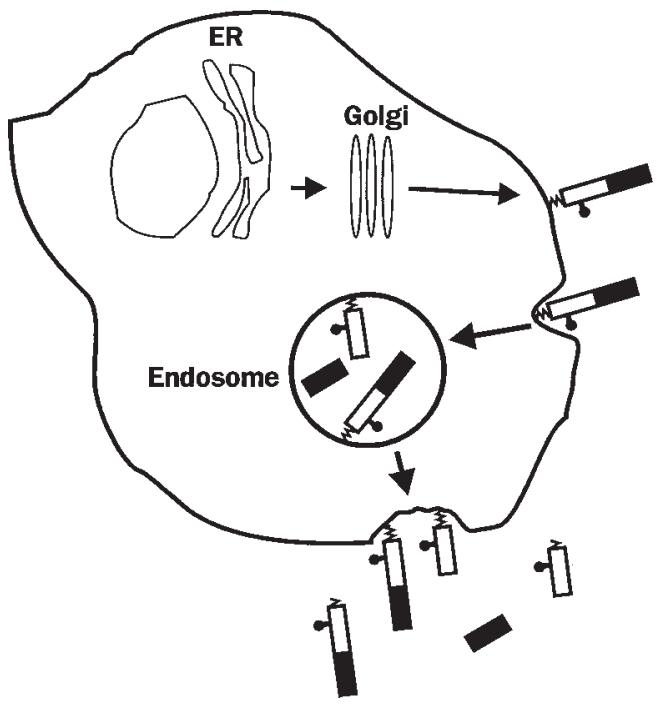

Figure 1. Cellular pathways followed by $\operatorname{PrP}^{\mathrm{C}}$. Like other membrane proteins, $\operatorname{PrP}^{\mathrm{C}}$ is synthesized in the rough $\mathrm{ER}$, and after passage through the Golgi, reaches the cell surface. $\operatorname{PrP}^{\mathrm{C}}$ on the plasma membrane is internalized into early endosomes, from which $95 \%$ of the molecules are recycled intact to the cell surface. $5 \%$ of the endocytosed molecules are proteolytically cleaved near residues $108-111$, and the Nand C-terminal cleavage products are externalized. Some of the membrane-anchored protein is also released into the medium by a second cleavage that occurs within the GPI anchor structure. Reprinted from: Shyng, S.-L., Huber, M.T. and Harris, D.A. 1993. J. Biol. Chem. 268:15922-15928. 
$\mathrm{PrP}^{\mathrm{C}}$ is subject to a proteolytic cleavage in its mid-region (6) that is inhibited by lysosomotropic amines and leupeptin, suggesting that it occurs within an endosomal compartment that is acidic and protease-containing. This endocytic recycling pathway is of interest because it may be the route along which certain steps in the conversion of $\mathrm{PrP}^{\mathrm{C}}$ to $\mathrm{PrP}^{\mathrm{Sc}}$ take place $(7,8)$. In addition, the existence of this pathway suggests that one physiological function of $\mathrm{PrP}^{\mathrm{C}}$ might be to facilitate uptake of an as yet unidentified extracellular ligand, by analogy with receptors responsible for uptake of transferrin and low-density lipoprotein.

We have found that clathrin-coated pits and vesicles are the morphological structures responsible for endocytic uptake of $\operatorname{PrP}^{\mathrm{C}}$ (9). This conclusion is based on immunogold localization of $\mathrm{PrP}^{\mathrm{C}}$ in these organelles by electron microscopy, inhibition of $\mathrm{PrP}^{\mathrm{C}}$ internalization by incubation of cells in hypertonic sucrose which disrupts clathrin lattices, and detection of $\operatorname{PrP}^{\mathrm{C}}$ in purified preparations of coated vesicles from brain. We hypothesize that $\mathrm{PrP}^{\mathrm{C}}$ molecules enter clathrin-coated pits after exiting cholesterol-rich raft domains on the plasma membrane (10).

The involvement of clathrin-coated pits in endocytosis of $\mathrm{PrP}^{\mathrm{C}}$ is surprising, since GPI-anchored proteins like $\mathrm{PrP}^{\mathrm{C}}$ lack a cytoplasmic domain that could interact directly with the intracellular components of coated pits such as clathrin and adapter proteins. Indeed, it has been speculated that other GPI-anchored proteins are excluded from coated pits, and are internalized via caveolae (11). To explain this paradox, we have postulated the existence of a "PrPC receptor", a transmembrane protein that has a coated-pit localization signal in its cytoplasmic domain, and whose extracellular domain binds the $\mathrm{N}$-terminal portion of $\operatorname{PrP}^{\mathrm{C}}(12)$ (Figure 2). This model is consistent with our observation that deletions within the $\mathrm{N}$-terminal domain of $\operatorname{PrP}^{\mathrm{C}}$ diminish internalization of the protein measured biochemically, and reduce its concentration in coated pits determined morphometrically (13). We presume that these deletions

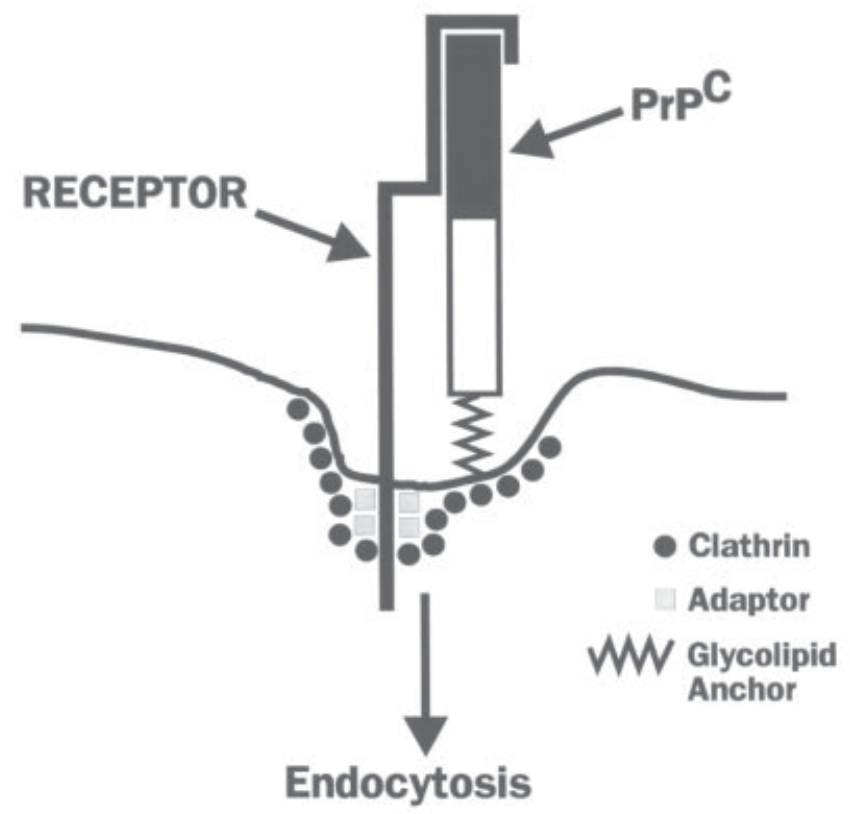

Figure 2. Model for the function of a putative $\operatorname{PrP}^{\mathrm{C}}$ receptor. Reprinted from: Harris, D.A., Gorodinsky, A., Lehmann, S., Moulder, K. and Shyng, S.-L. 1996. Curr. Top. Microbiol. Immunol. 207:77-93. 
reduce the affinity of $\mathrm{PrP}^{\mathrm{C}}$ for the endocytic receptor. Identification of this receptor is now of great importance, as it is likely to provide clues to the normal function of $\mathrm{PrP}^{\mathrm{C}}$, and may allow design of therapeutic strategies for blocking endocytic uptake of $\mathrm{PrP}^{\mathrm{C}}$, thereby inhibiting prion replication. Such a receptor might also be involved in the conversion of $\mathrm{PrP}^{\mathrm{C}}$ into $\mathrm{PrP}^{\mathrm{Sc}}$, or in the initial uptake of $\mathrm{PrP}^{\mathrm{Sc}}$-containing prion particles into cells.

\section{Formation of PrPSc in Cultured Cells}

\section{Cell Culture Models of Infectious and Familial Prion Diseases}

Several different cell lines can be infected with prions from scrapie-infected rodent brain, including N2a mouse neuroblastoma cells $(14,15)$, immortalized $\mathrm{HaB}$ hamster brain cells (16), PC12 rat pheochromocytoma cells (17), and immortalized GT1 mouse hypothalamic neurons (18). These cells can be propagated continuously in culture in an infected state, and can be shown to produce $\mathrm{PrP}^{\mathrm{Sc}}$ by biochemical criteria, and infectivity by animal bioassay. Surprisingly, they show no obvious cytopathology, with the exception of the GT1 cells, a sub-population of which appears to undergo apoptosis. A great deal has been learned about the cellular mechanisms underlying $\mathrm{PrP}^{\mathrm{Sc}}$ formation using these cells, which can be regarded as models of the infectious manifestation of prion diseases.

We have been interested in developing a cell culture model of familial prion diseases, which are associated with point or insertional mutations in the PrP gene on chromosome $20(19,20)$. To model these diseases, we have created stably transfected lines of Chinese hamster ovary $(\mathrm{CHO})$ cells that express mouse PrP (moPrP) molecules carrying mutations homologous to six different pathogenic mutations of humans. As a negative control, we have also analyzed cells expressing moPrP with a substitution of valine for methionine at codon 128, homologous to the nonpathogenic polymorphism at codon 129 in human PrP.

We find that the moPrPs carrying pathogenic mutations acquire all of the biochemical hallmarks of $\operatorname{PrP}^{\mathrm{Sc}}(21,22)$. $\mathrm{PrP}^{\mathrm{Sc}}$ can be distinguished operationally from $\mathrm{PrP}^{\mathrm{C}}$ by several operational biochemical properties. One commonly used property is insolubility in non-denaturing detergents, which can be assayed by subjecting detergent lysates to ultracentrifugation. We observed that while most the wild-type PrP remained in the supernatant under these conditions, the majority of each of the PrPs carrying a pathogenic mutation was found in the pellet (Figure $3 \mathrm{~A}$ ). As expected, M128V moPrP behaved like the wild-type protein. A second characteristic of $\mathrm{PrP}^{\mathrm{Sc}}$ is resistance to proteolysis, which is manifested by production of protease-resistant core fragment ( $\mathrm{PrP}$ 27-30) upon treatment with proteinase $K$. Treatment of the mutant PrPs with $3.3 \mu \mathrm{g} / \mathrm{ml}$ proteinase $\mathrm{K}$ for 10 minutes resulted in production of a PrP 27-30 fragment, while under the same conditions wild-type and M128V moPrPs were completely digested (Figure 3B). A third distinguishing feature of $\mathrm{PrP}^{\mathrm{Sc}}$ is related to the glycosylphosphatidylinositol (GPI) anchor that attaches the C-terminus of the protein to the cell membrane. Although both isoforms contain a GPI anchor, $\mathrm{PrP}^{\mathrm{Sc}}$, in contrast to $\mathrm{PrP}^{\mathrm{C}}$, cannot be released from membranes of scrapie-infected cells and brain by a bacterial phospholipase (PIPLC) that specifically cleaves the GPI anchor $(21,23)$. We found that the same is true for moPrP molecules carrying pathogenic mutations that are expressed in CHO cells (24). Other similarities between mutant PrPs produced in $\mathrm{CHO}$ cells and authentic, infectious $\mathrm{PrP}^{\mathrm{Sc}}$ include slow metabolic generation and turnover (22), and the existence of small differences among different mutant PrPs in proteinase $\mathrm{K}$ cleavage site and glycosylation pattern that are reminiscent of the strain-specific characteristics of natural prion isolates (21).

Taken together, our results make it clear that the $\mathrm{CHO}$ cell system is recapitulating the essential features of $\mathrm{PrP}^{\mathrm{Sc}}$ biogenesis seen in vivo. Although we have not yet demonstrated that mutant PrPs produced in these cells are infectious, this system has already provided key insights into several aspects of prion biology, as outlined below. 


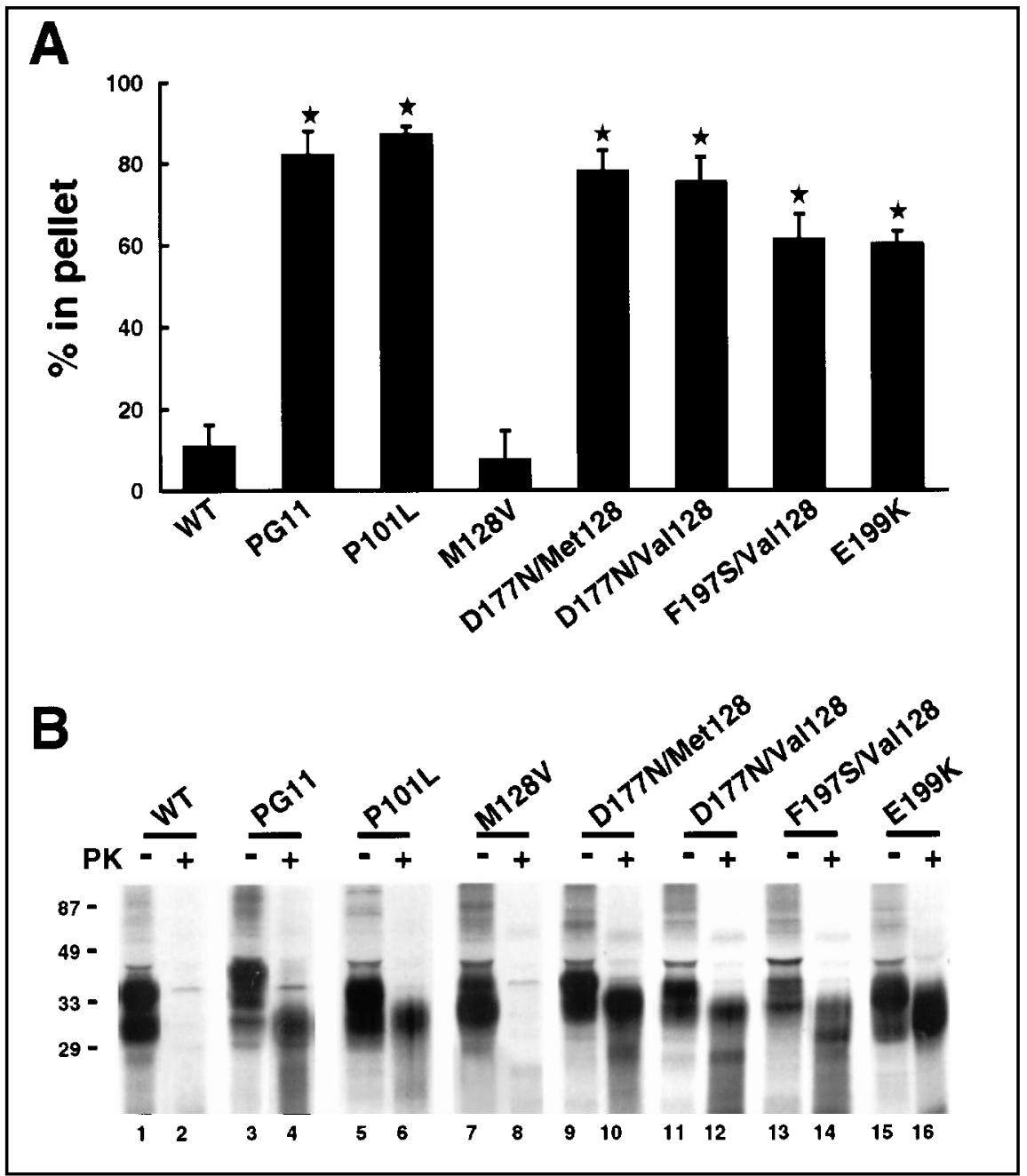

Figure 3. MoPrPs carrying disease-related mutations are detergent-insoluble and protease-resistant when expressed in cultured CHO cells. Panel A: Lysates of metabolically labeled CHO cells expressing each moPrP were centrifuged first at $16,000 \mathrm{x} g$ for $5 \mathrm{~min}$, and then at 265,000 $\mathrm{x}$ g for $40 \mathrm{~min}$. MoPrP in the supernatants and pellets from the second centrifugation was quantitated by immunoprecipitation, and the percentage of PrP in the pellet was calculated. Each bar represents the mean \pm SD of values from three experiments. Values that are significantly different from wild-type (WT) moPrP by t-test $(\mathrm{p}<0.001)$ are indicated by an asterisk. WT, wild-type; PG11, six-octapeptide insertion. Panel B: Proteins in lysates of metabolically labeled cells were either digested at $37^{\circ} \mathrm{C}$ for 10 minutes with $3.3 \mathrm{mg} / \mathrm{ml}$ of proteinase $\mathrm{K}$ (+ lanes), or were untreated (- lanes), prior to recovery of moPrP by immunoprecipitation and analysis by SDS-PAGE. Five times as many cell-equivalents were loaded in the + lanes as in the - lanes. Reprinted from: Harris, D.A. and Lehmann, S. 1997. In: Alzheimer's Disease: Biology, Diagnosis and Therapeutics. K Iqbal, B.Winblad, T. Nishimura, M.Takeda and H.M. Wisniewski, eds. pp. 631-43. 


\section{PIPLC-resistance of PrPSc}

Several hypotheses can be envisioned to explain why mutant $\operatorname{PrP}$ (and by implication $\mathrm{PrP}^{\mathrm{Sc}}$ ) is not released from cell membranes by PIPLC (24) (Figure 4). First, it is possible that the molecule has a second mechanism of membrane attachment in addition to the GPI anchor, such as integration of the PrP polypeptide chain into the lipid bilayer or tight binding to another membrane protein. In favor of this explanation, we find that ${ }^{3} \mathrm{H}$ [fatty acid] label incorporated into mutant $\operatorname{PrP}$ is partially removed upon treatment of intact cells with PIPLC, even though virtually all of the protein remains tightly associated with the cell membrane (24). Alternatively, the GPI anchor of $\mathrm{PrP}^{\mathrm{Sc}}$ could be physically shielded from the phospholipase, either by aggregation of the protein or by intrinsic conformational features of the polypeptide chain. This mechanism may also be operative, based on our observation that some mutant PrP molecules remain resistant to PIPLC cleavage after extraction into Triton lysis buffer, but not after boiling in SDS, which would unfold the polypeptide chain and disrupt any intermolecular aggregates (Narwa and Harris, unpublished data). Clearly, further work will be needed to determine the relative contributions of these different models.

\section{Kinetics of PrPSc Formation}

Pulse-chase metabolic labeling experiments indicate that conversion of mutant PrPs to the $\mathrm{PrP}^{\mathrm{Sc}}$ state is a step-wise process, with distinct biochemical intermediates being generated in different cellular compartments (25) (Figure 5). The earliest event

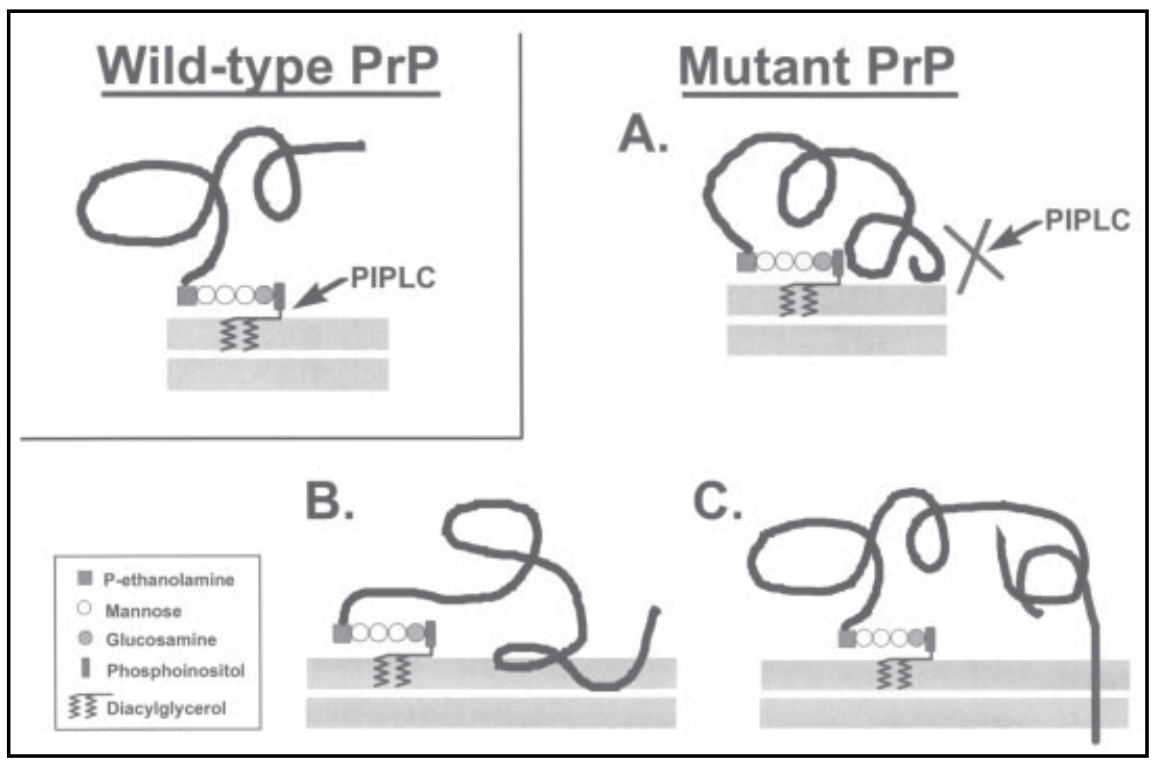

Figure 4. Models to explain why PIPLC releases $\operatorname{PrP}^{\mathrm{C}}$ but not $\mathrm{PrP}^{\mathrm{Sc}}$ from cell membranes. Wild-type $\left.\operatorname{PrP}(\operatorname{PrP})^{\mathrm{C}}\right)$ is anchored to the membrane exclusively by its GPI anchor, the core structure of which is illustrated, along with the site cleaved by PIPLC. The polypeptide chain of mutant $\operatorname{PrP}\left(\mathrm{PrP}^{\mathrm{Sc}}\right)$ may adopt a conformation that physically blocks access of PIPLC to the anchor (A). Alternatively, the polypeptide chain of the mutant protein may be integrated into the lipid bilayer (B), or bind tightly to another membrane-associated molecule (C); in these last two cases, the PrP molecule would be retained on the membrane even after the anchor is cleaved. Reprinted from: Harris, D.A. 1998. In: GPI-Anchored Biomolecules. S. Ilangumaran and D.C. Hoessli, eds. 
is the acquisition of PIPLC-resistance, which is detectable within minutes of pulselabeling, and is not blocked by incubation of cells at $18^{\circ} \mathrm{C}$ or treatment with brefeldin A. This step is therefore likely to occur in the ER, either during or very soon after completion of the polypeptide chain, and we speculate that it reflects the actual conformational switch to the $\mathrm{PrP}^{\mathrm{Sc}}$ state. This idea is attractive, because the ER is the location where proteins normally fold, and because this compartment contains a number of molecular chaperones that are good candidates for the cofactors or "protein X" molecules that are widely thought to play a critical role in prion formation (4, 26).

In contrast to PIPLC-resistance, detergent-insolubility requires at least 30 minutes of chase to be detected, and protease-resistance even longer (up to 6 hours). These latter two steps are therefore likely to take place subsequent to delivery of the protein to cell surface, either on the plasma membrane itself, or along an endocytic pathway. Cholesterol-rich membrane "rafts" (27) may play a role in acquisition of detergent-insolubility and protease-resistance, perhaps by forcing $\operatorname{PrP}$ molecules together in a small space. In support of this hypothesis, we find that GPI-anchored $\mathrm{PrP}$ is present in rafts (10), and that artificially constructed transmembrane forms of mutant PrP (which would be excluded from rafts) never develop these two properties (Daude and Harris, unpublished data). Rafts, however, are not likely to be involved in formation of the PIPLC-resistant intermediate in the ER, since these membrane domains first form in the Golgi and are absent from the ER.

\section{Lack of Interaction Between Mutant and Wild-type PrPs in the Same Cell}

Almost all patients with inherited prion diseases are heterozygous for the mutant allele, implying that their cells express both mutant and wild-type PrPs . To model this situation, we have prepared stably transfected lines of $\mathrm{CHO}$ cells that express

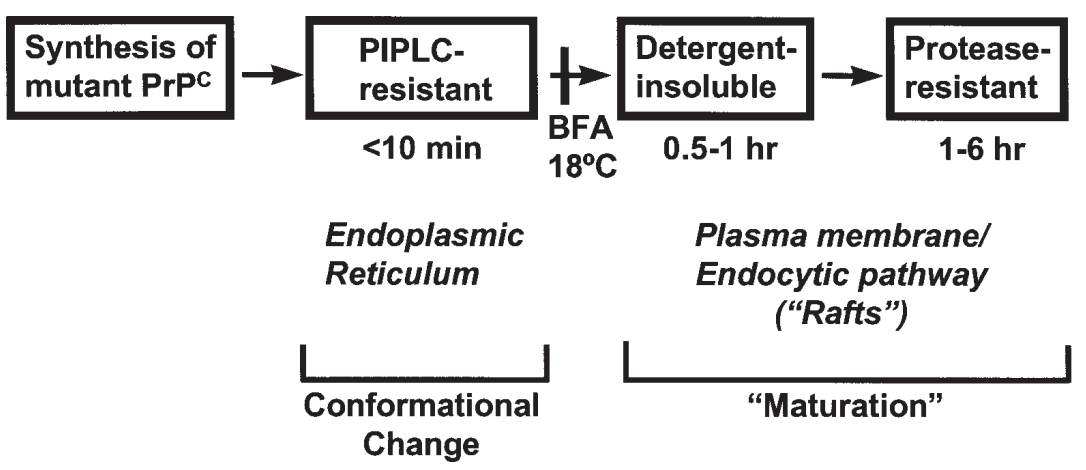

Figure 5. A scheme for transformation of mutant $\operatorname{PrPs}$ to a $\operatorname{PrP}^{\mathrm{Sc}}$ state. Mutant $\operatorname{PrPs}$ are initially synthesized in the $\operatorname{PrP}^{\mathrm{C}}$ state, and acquire $\mathrm{PrP}^{\mathrm{Sc}}$ properties in a stepwise fashion as they pass through the endoplasmic reticulum and arrive at the plasma membrane. PIPLC-resistance reflects folding of the polypeptide chain into the $\mathrm{PrP}^{\mathrm{Sc}}$ conformation, while detergent-insolubility and protease-resistance result from subsequent intermolecular aggregation ("maturation"). The times given underneath the boxes indicate when after pulselabeling the corresponding property is detected. Addition of brefeldin A (BFA) to cells or incubation at $18^{\circ} \mathrm{C}$, treatments which block movement of proteins beyond the Golgi apparatus, inhibit acquisition of detergent-insolubility and protease-resistance but not PIPLC-resistance. Adapted from: Daude, N., Lehmann, S. and Harris, D.A. 1997. J. Biol. Chem. 272:11604-11612. 
both wild-type moPrP and moPrP carrying a six-octapeptide insertion whose human homologue is associated with familial CJD (28). This particular mutant protein was chosen because it can be readily distinguished from wild-type PrP on SDS-PAGE by its lower electrophoretic mobility. We find that wild-type moPrP does not acquire any of the biochemical properties of $\mathrm{PrP}^{\mathrm{Sc}}$ when co-expressed with the mutant moPrP. Conversely, conversion of the mutant protein to the $\mathrm{PrP}^{\mathrm{Sc}}$ state is not impaired by co-expression of the wild-type protein. These results in CHO cells stand in contrast to the situation in the brains of CJD patients with the same mutation, in which the wild-type protein becomes both detergent-insoluble and protease-resistant (29). This raises the intriguing possibility that $\mathrm{CHO}$ cells lack some factor present in neurons that may be crucial for the productive interaction of wild-type and mutant PrP molecules. It is also noteworthy that inter-allelic interaction may also depend on the mutation being expressed: in patients with familial prion diseases, some mutant PrP molecules are able to fully convert the wild-type protein to the $\mathrm{PrP}^{\mathrm{Sc}}$ state, some induce partial conversion, and some have no effect (29-31).

\section{Blockade of Glycosylation Promotes Acquisition of PrPSc Properties}

Although $\mathrm{PrP}^{\mathrm{Sc}}$ can be generated in the absence of glycosylation (32), there is evidence that oligosaccharide chains can modify the efficiency of the conversion process $(32,33)$, and may also serve as molecular markers of diverse prion strains (34-36). To investigate the role of N-glycans in determining the properties of PrP, we have expressed in transfected $\mathrm{CHO}$ cells mouse PrP molecules in which Nglycosylation has been blocked either by treatment with the drug tunicamycin, or by substitution of alanine for threonine at one or both of the $\mathrm{N}-\mathrm{X}-\mathrm{T}$ consensus sites (37). We first determined the effects of these manipulations on the biosynthesis and trafficking of the protein. We found that PrP molecules mutated at threonine-182 alone or at both threonine-182 and threonine-198 fail to reach the cell surface after synthesis, but that those mutated at threonine-198 or synthesized in the presence of tunicamycin can be detected on the plasma membrane. This indicates that N-linked glycans are not essential for normal trafficking of PrP, and that mutational inactivation of the consensus site that includes threonine-182 alters trafficking of the protein in a way that is independent of an effect on oligosaccharide attachment.

We also found that all three PrP glycosylation mutants acquire the biochemical attributes of $\mathrm{PrP}^{\mathrm{Sc}}$, including detergent-insolubility, protease-resistance, and PIPLCresistance. This result was not unexpected, since an equivalent mutation in the second glycosylation consensus site of human PrP (T183A) has recently been associated with a familial spongiform encephalopathy in a Brazilian family (38). What was surprising, however, was that wild-type PrP synthesized in the presence of tunicamycin also displayed $\mathrm{PrP}^{\mathrm{Sc}}$-like properties, although to a lesser degree than the mutant PrPs. There are several possible explanations for this phenomenon, including the possibility that the absence of $\mathrm{N}$-glycans favors formation of a transitional state that is intermediate between $\mathrm{PrP}^{\mathrm{C}}$ and $\mathrm{PrP}^{\mathrm{Sc}}$. Taken together, our results suggest that the PrP molecule has an intrinsic tendency to acquire some $\mathrm{PrP}^{\mathrm{Sc}}$-like properties, and that $\mathrm{N}$-glycan chains protect against this change. However, pathogenic mutations, or presumably contact with exogenous prions, are necessary to fully convert the protein to a $\operatorname{PrP}^{\mathrm{Sc}}$ state.

\section{Conclusions}

The application of a cell biological approach to the study of prion diseases has allowed us to define the normal trafficking pathways followed by $\operatorname{PrP}^{\mathrm{C}}$, and to develop a cell culture system for the de novo formation of $\mathrm{PrP}^{\mathrm{Sc}}$ from $\mathrm{PrP}$ molecules carrying pathogenic mutations. The information we have obtained complements what is being learned from in vitro systems and from transgenic mice. A number of important 
questions remain, including identifying the $\operatorname{PrP}^{\mathrm{C}}$ receptor that mediates endocytosis of $\mathrm{PrP}^{\mathrm{C}}$ via clathrin-coated pits, and determining which ER chaperone molecules play a role in formation of the earliest, PIPLC-resistant intermediate along the pathway to $\mathrm{PrP}^{\mathrm{Sc}}$. Finally, it will be crucial to characterize the cell biology of $\mathrm{PrP}^{\mathrm{C}}$ and $\mathrm{PrPSc}$ in neurons, astrocytes, lymphocytes, and other differentiated cell types that are relevant to prion biology, as opposed to the transformed cell lines that have been utilized for all of our experiments to date. This should now be possible, using cells cultured directly from the brains and peripheral tissues of mice with normal or genetically altered PrP genes.

\section{Acknowledgements}

Work in the author's laboratory has been supported by grants from the National Institutes of Health and the Alzheimer's Association.

\section{References}

1. Prusiner, S.B., Scott, M.R., DeArmond, S.J. and Cohen, F.E. 1998. Prion protein biology. Cell. 93: 337-348.

2. Prusiner, S.B., Scott, M., Foster, D., Pan, K.M., Groth, D., Mirenda, C., Torchia, M., Yang, S.L., Serban, D., Carlson, G.A., Hoppe, P.C., Westaway, D. and DeArmond, S.J. 1990. Transgenetic studies implicate interactions between homologous PrP isoforms in scrapie prion replication. Cell. 63: 673-686.

3. Cohen, F.E., Pan, K.M., Huang, Z., Baldwin, M., Fletterick, R.J. and Prusiner, S.B. 1994. Structural clues to prion replication. Science. 264: 530-531.

4. Welch, W.J. and Gambetti, P. 1998. Chaperoning brain diseases. Nature. 392: 23-24.

5. Shyng, S.L., Huber, M.T. and Harris, D.A. 1993. A prion protein cycles between the cell surface and an endocytic compartment in cultured neuroblastoma cells. J. Biol. Chem. 268: 15922-15928.

6. Harris, D.A., Huber, M.T., van Dijken, P., Shyng, S.-L., Chait, B.T. and Wang, R. 1993. Processing of a cellular prion protein: Identification of N- and Cterminal cleavage sites. Biochem. 32: 1009-1016.

7. Borchelt, D.R., Taraboulos, A. and Prusiner, S.B. 1992. Evidence for synthesis of scrapie prion proteins in the endocytic pathway. J. Biol. Chem. 267: 1618816199.

8. Caughey, B. and Raymond, G.J. 1991. The scrapie-associated form of PrP is made from a cell surface precursor that is both protease- and phospholipasesensitive. J. Biol. Chem. 266: 18217-18223.

9. Shyng, S.L., Heuser, J.E. and Harris, D.A. 1994. A glycolipid-anchored prion protein is endocytosed via clathrin-coated pits. J. Cell Biol. 125: 1239-1250.

10. Gorodinsky, A. and Harris, D.A. 1995. Glycolipid-anchored proteins in neuroblastoma cells form detergent-resistant complexes without caveolin. J. Cell Biol. 129: 619-627.

11. Anderson, R.G.W. 1993. Plasmalemmal caveolae and GPI-anchored membrane proteins. Curr. Op. Cell Biol. 5: 647-652.

12. Harris, D.A., Gorodinsky, A., Lehmann, S., Moulder, K. and Shyng, S.-L. 1996. Cell biology of the prion protein. Curr. Top. Microbiol. Immunol. 207: 77-93.

13. Shyng, S.L., Moulder, K.L., Lesko, A. and Harris, D.A. 1995. The N-terminal domain of a glycolipid-anchored prion protein is essential for its endocytosis via clathrin-coated pits. J. Biol. Chem. 270: 14793-14800.

14. Butler, D.A., Scott, M.R.D., Bockman, J.M., Borchelt, D.R., Taraboulos, A., Hsiao, K.K., Kingsbury, D.T. and Prusiner, S.B. 1988. Scrapie-infected murine neuroblastoma cells produce protease-resistant prion proteins. J. Virol. 62: 15581564. 
15. Race, R.E., Caughey, B., Graham, K., Ernst, D. and Chesebro, B. 1988. Analyses of frequency of infection, specific infectivity, and prion protein biosynthesis in scrapie-infected neuroblastoma cell clones. J. Virol. 62: 2845-2849.

16. Taraboulos, A., Serban, D. and Prusiner, S.B. 1990. Scrapie prion proteins accumulate in the cytoplasm of persistently infected cultured cells. J. Cell Biol. 110: 2117-2132.

17. Rubinstein, R., Deng, H., Scalici, C.L. and Papini, M.C. 1991. Alterations in neurotransmitter-related enzyme activity in scrapie-infected PC12 cells. J. Gen. Virol. 72: 1279-1285.

18. Schätzl, H.M., Laszlo, L., Holtzman, D.M., Tatzelt, J., Dearmond, S.J., Weiner, R.I., Mobley, W.C. and Prusiner, S.B. 1997. A hypothalamic neuronal cell line persistently infected with scrapie prions exhibits apoptosis. J. Virol. 71: 88218831.

19. Prusiner, S.B. and Hsiao, K.K. 1994. Human prion diseases. Ann. Neurol. 35: 385-395.

20. Parchi, P. and Gambetti, P. 1995. Human prion diseases. Curr. Op. Neurol. 8: 286-293.

21. Lehmann, S. and Harris, D.A. 1996. Mutant and infectious prion proteins display common biochemical properties in cultured cells. J. Biol. Chem. 271: 16331637.

22. Lehmann, S. and Harris, D.A. 1996. Two mutant prion proteins expressed in cultured cells acquire biochemical properties reminiscent of the scrapie isoform. Proc. Natl. Acad. Sci. USA. 93: 5610-5614.

23. Stahl, N., Borchelt, D.R. and Prusiner, S.B. 1990. Differential release of cellular and scrapie prion proteins from cellular membranes by phosphatidylinositolspecific phospholipase C. Biochem. 29: 5405-5412.

24. Lehmann, S. and Harris, D.A. 1995. A mutant prion protein displays an aberrant membrane association when expressed in cultured cells. J. Biol. Chem. 270: 24589-24597.

25. Daude, N., Lehmann, S. and Harris, D.A. 1997. Identification of intermediate steps in the conversion of a mutant prion protein to a scrapie-like form in cultured cells. J. Biol. Chem. 272: 11604-11612.

26. Telling, G.C., Scott, M., Mastriani, J., Gabizon, R., Torchia, M., Cohen, F.E., DeArmond, S.J. and Prusiner, S.B. 1995. Prion propagation in mice expressing human and chimeric PrP transgenes implicates the interaction of cellular PrP with another protein. Cell. 83: 79-90.

27. Simons, K. and Ikonen, E. 1997. Functional rafts in cell membranes. Nature. 387: 569-572.

28. Lehmann, S., Daude, N. and Harris, D.A. 1997. A wild-type prion protein does not acquire properties of the scrapie isoform when coexpressed with a mutant prion protein in cultured cells. Mol. Brain Res. 52: 139-145.

29. Chen, S.G., Parchi, P., Brown, P., Capellari, S., Zou, W.Q., Cochran, E.J., Vnencakjones, C.L., Julien, J., Vital, C., Mikol, J., Lugaresi, E., Autilio-Gambetti, L. and Gambetti, P. 1997. Allelic origin of the abnormal prion protein isoform in familial prion diseases. Nature Med. 3: 1009-1015.

30. Tagliavini, F., Prelli, F., Porro, M., Rossi, G., Giaccone, G., Farlow, M.R., Dlouhy, S.R., Ghetti, B., Bugiani, O. and Frangione, B. 1994. Amyloid fibrils in Gerstmann-Sträussler-Scheinker disease (Indiana and Swedish kindreds) express only PrP peptides encoded by the mutant allele. Cell. 79: 695-703.

31. Gabizon, R., Telling, G., Meiner, Z., Halimi, M., Kahana, I. and Prusiner, S.B. 1996. Insoluble wild-type and protease-resistant mutant prion protein in brains of patients with inherited prion disease. Nature Med. 2: 59-64.

32. Taraboulos, A., Rogers, M., Borchelt, D.R., McKinley, M.P., Scott, M., Serban, D. and Prusiner, S.B. 1990. Acquisition of protease resistance by prion proteins in scrapie-infected cells does not require asparagine-linked glycosylation. Proc. 
Natl. Acad. Sci. USA. 87: 8262-8266.

33. Dearmond, S.J., Sanchez, H., Yehiely, F., Qiu, Y., Ninchakcasey, A., Daggett, V., Camerino, A.P., Cayetano, J., Rogers, M., Groth, D., Torchia, M., Tremblay, P., Scott, M.R., Cohen, F.E. and Prusiner, S.B. 1997. Selective neuronal targeting in prion disease. Neuron. 19: 1337-1348.

34. Parchi, P., Castellani, R., Capellari, S., Ghetti, B., Young, K., Chen, S.G., Farlow, M., Dickson, D.W., Sima, A.A.F., Trojanowski, J.Q., Petersen, R.B. and Gambetti, P. 1996. Molecular basis of phenotypic variability in sporadic Creutzfeldt-Jakob disease. Ann. Neurol. 39: 767-778.

35. Collinge, J., Sidle, K.C.L., Meads, J., Ironside, J. and Hill, A.F. 1996. Molecular analysis of prion strain variation and the aetiology of 'new variant' CJD. Nature. 383: 685-690.

36. Monari, L., Chen, S.G., Brown, P., Parchi, P., Petersen, R.B., Mikol, J., Gray, F., Cortelli, P., Montagna, P., Ghetti, B., Goldfarb, L., Gajdusek, D.C., Lugaresi, E., Gambetti, P. and Autilio-Gambetti, L. 1994. Fatal familial insomnia and familial Creutzfeldt-Jakob disease: Different prion proteins determined by a DNA polymorphism. Proc. Natl. Acad. Sci. USA. 91: 2839-2842.

37. Lehmann, S. and Harris, D.A. 1997. Blockade of glycosylation promotes acquisition of scrapie-like properties by the prion protein in cultured cells. J. Biol. Chem. 272: 21479-21487.

38. Nitrini, R., Rosemberg, S., Passosbueno, M.R., Dasilva, L.S.T., Iughetti, P., Papadopoulos, M., Carrilho, P.M., Caramelli, P., Albrecht, S., Zatz, M. and Leblanc, A. 1997. Familial spongiform encephalopathy associated with a novel prion protein gene mutation. Ann. Neurol. 42: 138-146.

39. Harris, D.A. 1999. Prions: Molecular and Cellular Biology. Horizon Scientific Press, Wymondham, UK. 


\section{Further Reading}

Caister Academic Press is a leading academic publisher of advanced texts in microbiology, molecular biology and medical research. Full details of all our publications at caister.com

- MALDI-TOF Mass Spectrometry in Microbiology Edited by: M Kostrzewa, S Schubert (2016) www.caister.com/malditof

- Aspergillus and Penicillium in the Post-genomic Era Edited by: RP Vries, IB Gelber, MR Andersen (2016) www.caister.com/aspergillus2

- The Bacteriocins: Current Knowledge and Future Prospects Edited by: RL Dorit, SM Roy, MA Riley (2016)

www.caister.com/bacteriocins

- Omics in Plant Disease Resistance Edited by: V Bhadauria (2016) www.caister.com/opd

- Acidophiles: Life in Extremely Acidic Environments Edited by: R Quatrini, DB Johnson (2016) www.caister.com/acidophiles

- Climate Change and Microbial Ecology: Current Research and Future Trend

Edited by: J Marxsen (2016)

www.caister.com/climate

- Biofilms in Bioremediation: Current Research and Emerging Technologies

Edited by: G Lear (2016)

www.caister.com/biorem

- Microalgae: Current Research and Applications Edited by: MN Tsaloglou (2016) www.caister.com/microalgae

- Gas Plasma Sterilization in Microbiology: Theory, Applications, Pitfalls and New Perspectives Edited by: H Shintani, A Sakudo (2016) www.caister.com/gasplasma

- Virus Evolution: Current Research and Future Directions Edited by: SC Weaver, M Denison, M Roossinck, et al. (2016) www.caister.com/virusevol

- Arboviruses: Molecular Biology, Evolution and Control Edited by: N Vasilakis, DJ Gubler (2016) www.caister.com/arbo

- Shigella: Molecular and Cellular Biology Edited by: WD Picking, WL Picking (2016) www.caister.com/shigella

-Aquatic Biofilms: Ecology, Water Quality and Wastewater Treatment

Edited by: AM Romaní, H Guasch, MD Balaguer (2016)

www.caister.com/aquaticbiofilms

- Alphaviruses: Current Biology

Edited by: S Mahalingam, L Herrero, B Herring (2016)

www.caister.com/alpha

- Thermophilic Microorganisms

Edited by: F Li (2015)

www.caister.com/thermophile
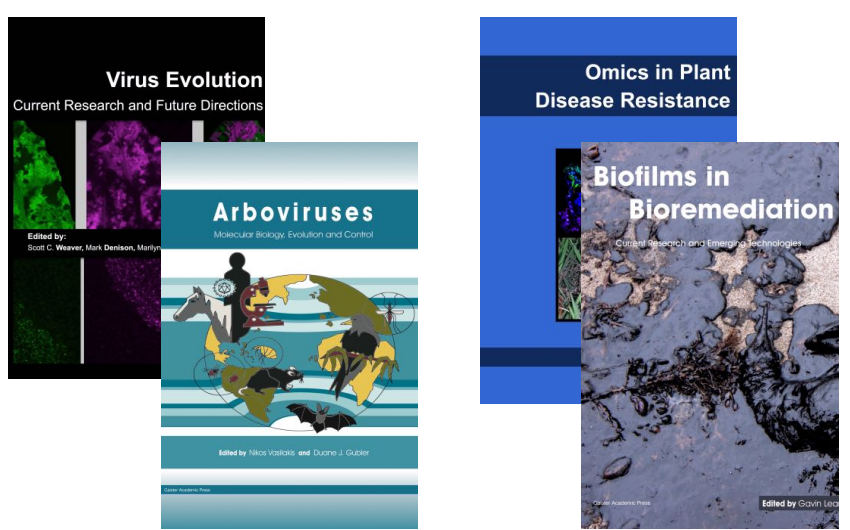
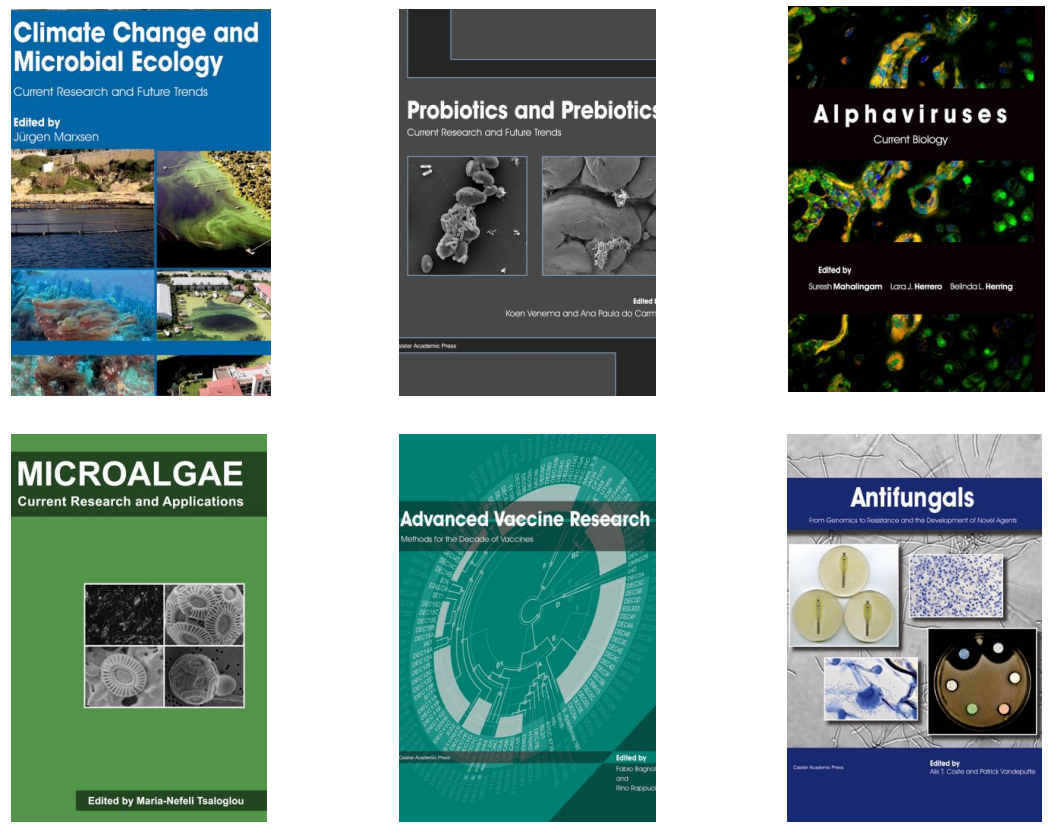

- Flow Cytometry in Microbiology: Technology and Applications Edited by: MG Wilkinson (2015) www.caister.com/flow

- Probiotics and Prebiotics: Current Research and Future Trends Edited by: K Venema, AP Carmo (2015) www.caister.com/probiotics

- Epigenetics: Current Research and Emerging Trends Edited by: BP Chadwick (2015) www.caister.com/epigenetics2015

- Corynebacterium glutamicum: From Systems Biology to Biotechnological Applications

Edited by: A Burkovski (2015)

www.caister.com/cory2

- Advanced Vaccine Research Methods for the Decade of Vaccines

Edited by: F Bagnoli, R Rappuoli (2015)

www.caister.com/vaccines

- Antifungals: From Genomics to Resistance and the Development of Novel Agents

Edited by: AT Coste, P Vandeputte (2015)

www.caister.com/antifungals

- Bacteria-Plant Interactions: Advanced Research and Future Trends Edited by: J Murillo, BA Vinatzer, RW Jackson, et al. (2015) www.caister.com/bacteria-plant

\section{- Aeromonas}

Edited by: J Graf (2015)

www.caister.com/aeromonas

- Antibiotics: Current Innovations and Future Trends

Edited by: S Sánchez, AL Demain (2015)

www.caister.com/antibiotics

- Leishmania: Current Biology and Contro Edited by: S Adak, R Datta (2015) www.caister.com/leish2

- Acanthamoeba: Biology and Pathogenesis (2nd edition) Author: NA Khan (2015)

www.caister.com/acanthamoeba2

- Microarrays: Current Technology, Innovations and Applications Edited by: Z He (2014)

www.caister.com/microarrays2

- Metagenomics of the Microbial Nitrogen Cycle: Theory, Methods and Applications

Edited by: D Marco (2014)

www.caister.com/n2 